Stawomir Sztobryn

(Łódź)

\title{
Historiografia pedagogiczna w czasopismach tradycyjnych i elektronicznych
}

\author{
Ten jest, że tak rzeke, jedyny pokarm dowcipu ludzkiego, \\ umieć $i$ wiedzieć jak najwięcej: \\ tym się karmi, tym się cieszy, tym się kontentuje \\ Z pierwszego numeru „Merkuriusza Polskiego Ordynaryjnego” z 1661r.
}

Czasopisma odgrywają niezwykle ważną rolę w popularyzacji wyników badań naukowych, ale nie we wszystkich dyscyplinach jest ona jednakowo doceniana. Widać to wyraźnie wtedy, gdy porównuje się liczbę czasopism tradycyjnych i elektronicznych w takich dyscyplinach, jak medycyna, przyrodoznawstwo i nauki techniczne z jednej strony, a szeroko rozumiane nauki humanistyczne z drugiej. Przewaga tych pierwszych jest ogromna. Ta różnica zapewne wynika ze specyfiki gromadzenia, wytwarzania oraz starzenia się wiedzy, ale z pewnością nie jest to jedyny czynnik.

Czasopiśmiennictwo jest zjawiskiem względnie młodym. Od momentu pojawienia się pierwszego czasopisma do dnia dzisiejszego minęło blisko 350 lat. Odległość między pierwszym naukowym czasopismem („Philosophical Transactios...”) a pierwszym elektronicznym czasopismem naukowym („Mental WorkLoad”) jest jeszcze mniejsza i wynosi 315 lat. Jak wynika z analiz M. Nahotko współczesne biblioteki dysponują już kilkudziesięciotysięcznymi tytułami periodyków elektronicznych, z których część (ok. $26 \%$ ) stanowią czasopisma z zakresu nauk humanistycznych ${ }^{1}$. Periodyki liczebnie przyrastały w postępie geometrycznym, co świadczy o ich wyjątkowym znaczeniu dla życia społecznego, politycznego, gospodarczego, kulturalnego.

Zainteresowanie naukowymi badaniami nad czasopismami w Polsce ma już pewną tradycję - pierwszy cykl wykładów poświęconych teorii prasy został wygłoszony we Wrocławiu w 1806 r., natomiast pierwsze syntetyczne omówienie historii polskiej prasy nastąpiło w $1896 \mathrm{r}$. i było dziełem wybitnego historyka literatury, ale i pedagoga,

\footnotetext{
${ }^{1}$ M. Nahotko, Naukowe czasopisma elektroniczne, Warszawa 2007, s. 44. Elektroniczna Biblioteka Czasopism rejestruje 1279 tytułów z zakresu edukacji.http://rzblx1.uni-regensburg.de/ezeit/searchres.phtml?bibi$\mathrm{d}=$ AAAAA\&colors $=7 \&$ lang=de \&jq type $1=\mathrm{KT} \& \mathrm{jq}$ _term $1=$ education
} 
P. Chmielowskiego. Jednakże pierwsza polska placówka badawcza programowo zorientowana na badania czasopism powstała w Warszawie w 1958 r. i była to Pracownia Historii Czasopiśmiennictwa Polskiego XIX i XX w., a pierwszym specjalistycznym pismem w całości podejmującym badania prasoznawcze był powstały w 1962 r. „Rocznik Historii Czasopiśmiennictwa Polskiego"2. Charakterystyczną cechą tych badań, szczególnie w początkowej fazie, było z jednej strony - rozproszenie i raczej działania indywidualne niż zespołowe, skoordynowane, a z drugiej strony - rozwijanie się najpierw opracowań historycznych, idiograficznych, by w następnym etapie przejść do konstruowania refleksji teoretycznej. Zjawisko to dotyczy w tym samym stopniu publicystyki, co i czasopism specjalistycznych, których krąg odbiorców jest co prawda mniejszy, ale bardziej zorientowany na naukowe opracowania syntetyczne.

Ciekawą kwestią retrogresywnie prezentującą obecne dylematy nowoczesnej nauki jest stosunek instytucjonalny i osobisty uczonych do najnowszych technik kodowania i przechowywania informacji naukowej. W latach 60 ubiegłego wieku takim przełomem wydawało się wprowadzenie do warsztatów uczonych, bibliotek i archiwów techniki mikrofilmowej. Dekadę wcześniej - w 1950 r. - powstał przy Bibliotece Narodowej Zakład Zbiorów Mikrofilmowych. Mikrofilm postrzegano jako nową postać książki, a więc można powiedzieć, że technika ta była stadium pośrednim między tradycyjną książką a jej współczesną wersją elektroniczną, gdzie tekst artykułu czy książki jest elementem wirtualnego świata sieci komputerowej. Pojawienie się mikrofilmów oceniane było jako przejaw nowej jakości w pracy naukowej, która kontrastowała z trwającą od dziesięcioleci stagnacją i konserwatyzmem³ ${ }^{3}$. Problemy, jakie wówczas dostrzeżono żywo przypominają obecne dylematy związane z prawem autorskim, z wartością prawną fotokopii, z przechowywaniem dziedzictwa kulturowego.

Gdy w roku 1995 na jednej z konferencji historyków wychowania mówiłem o wykorzystaniu komputera w badaniach historyczno-pedagogicznych, informacja ta wydawała się swoistym novum. Tymczasem na Zachodzie komputery były od dawna w powszechnym użyciu, a nawet istniały już pierwsze czasopisma elektroniczne ${ }^{4}$. $\mathrm{Z}$ jednej strony można potraktować to spostrzeżenie jako wskaźnik naszego opóźnienia w stosunku do UE i USA, ale jednocześnie zaledwie 15-letnie zahamowanie (biorąc pod uwagę nasze realia geopolityczne) w zakresie cyfryzacji dyscypliny jest dowodem na to, że nowe technologie wyrównują zaległości, przyspieszają przemiany i unifikują społeczeństwa wysoko rozwinięte.

Współcześnie w odniesieniu do czasopism obecnych na platformie elektronicznej posługujemy się dwoma terminami opisującymi stopień ich obecności w cyberprzestrzeni. Pojęcie digitalizacji oznacza swoisty stan przejściowy między czasopismami drukowa-

2 B. Petrozolin-Skowrońska, Bibliografia - analiza - synteza - warsztat (I). Badania nad dziejami czasopiśmiennictwa polskiego, „Przegląd Humanistyczny” 1976, nr 7, s. 65-81. Autorka marginalnie wspomina o czasopismach pedagogicznych, ale wymienia W. Okonia i S. Truchima jako historyków oświaty zainteresowanych ich naukową eksploracją.

${ }^{3}$ E. Tomaszewski, A. Wyczański, Mikrofilm nowa postać książki, „Przegląd Humanistyczny” 1962, nr 1, s. 185.

4 S. Sztobryn, Komputer i integracja historyków wychowania, w: Stan i perspektywy historii wychowania, red. W. Jamrożek, Poznań 1995, s. 78-82. 
nymi tradycyjnie a całkowicie wirtualnymi publikacjami, inaczej mówiąc digitalizacja jest kopią elektroniczną (np. tekst skanowany) tekstu opublikowanego w czasopiśmie opartym na nośniku papierowym, natomiast pojęcie cyfryzacji dotyczy publikacji całkowicie elektronicznej o specyficznych właściwościach wynikających z możliwości multimedialnych i hipertekstowych ${ }^{5}$.

W polskich zasobach internetowych brak szczegółowej informacji o rozwoju czasopism pedagogicznych i historyczno-pedagogicznych umieszczonych na platformie elektronicznej. Wzorem dla ewentualnych działań w przyszłości mogłoby być takie elektroniczne czasopismo - ukazujące się od 2001 r. - jak „Kultura i Historia”, w którym za zamieszczone publikacje MNiSW przyznało aż 6 punktów ${ }^{6}$. W czasopiśmie tym są również teksty z pogranicza pedagogiki i historii.

Warto dodać, że w specjalistycznej wyszukiwarce ARIANTA ${ }^{7}$ znajduje się zaledwie 12 tytułów, które spełniają jednocześnie trzy kryteria (udostępnienie pełnych tekstów, występowanie tylko w postaci cyfrowej i przydzielone punkty MNiSW), a wśród nich jedynie „Kultura i Historia”, która zamieszcza artykuły z interesującej nas dziedziny. Przeglądarka oferuje ponadto podgląd 108 tytułów czasopism, które zaliczone są do dziedziny pedagogiki. Wyszukiwarka ARIANTA, która służy do odnajdywania czasopism naukowych w wersji elektronicznej w dziedzinie pedagogika wymienia 79 tytułów (występujących w formie drukowanej i on-line) i tylko 4 wyłącznie on-line („Moja Fizyka”, „Pedagogika Filozoficzna on-line”, „Trendy. Uczenie się w XXI wieku” oraz „Wirtualna Edukacja” wydawana po polsku w Nowej Zelandii). Żadne czasopismo pedagogiczne, dostępne on-line a występujące w prezentowanej bazie nie otrzymało punktów MNiSW. Abstrakty umieszcza 28 czasopism. Spośród tych ostatnich tematykę historyczno-pedagogiczną podejmuje tylko „Pedagogika Filozoficzna on-line”.

Wśród czasopism umieszczonych w ARIANCIE tylko „Chowanna” z lat 2003-2009 oferuje dostęp do pełnotekstowej wersji PDF. Natomiast stricte historyczno-pedagogiczny periodyk „Biuletyn Historii Wychowania” prezentuje wyłącznie spisy treści roczników 2005/6 oraz 20079 . Istnieją również w Sieci wortale, które udostępniają w systemie Open Access (OA) czasopisma digitalizowane. Przykładem może być Pedagogiczna Biblioteka Cyfrowa oferująca skanowane czasopisma, w tym m.in. „Miesięcznik Pedagogiczny” (rok 12 i 13) „Chorał” (rocznik 1904 i 1905) oraz wybrane roczniki serii „Anneles Academiae Paedagogicae Cracviensis”.

\footnotetext{
${ }^{5}$ M. i M. Nahotko, Stopień cyfryzacji polskich czasopism naukowych, http://nahotko.webpark.pl/xvinib.pdf

${ }^{6}$ Za udostępnienie streszczeń lub pełnych tekstów na stronie internetowej można uzyskać jedynie 0,5 punktu. Biorąc pod uwagę walory czasopism elektronicznych jest to wartość minimalna (max 6 punktów) raczej niestymulująca do posłużenia się tym nośnikiem. Cyfryzacja czasopism jest zjawiskiem globalnym i nieuniknionym, a w związku z tym decydenci powinni raz jeszcze przemyśleć zasady polityki punktowania rozpraw umieszczanych na platformie elektronicznej.

7 Autorami są A. Drabek i A. Pulikowski. http://www1.bg.us.edu.pl/bazy/czasopisma/czasop_full. asp?d=1198

${ }^{8}$ http://www1.bg.us.edu.pl/bazy/czasopisma/szukaj_czasop.asp [dane sprawdzone 14.10.2009 r.]

${ }^{9} \mathrm{Na}$ podstawie wypowiedzi ustnej redaktora naczelnego tego czasopisma w najbliższym czasie należy spodziewać się digitalizacji wersji papierowej.
} 
Z badań bibliotekoznawcy - M. Nahotko - prezentujących czasopisma elektroniczne w skali globalnej można wysunąć pewne konsekwencje dotyczące stanu cyfryzacji naszej dyscypliny. Wskazuje on, że 93\% światowej publikacji czasopiśmienniczej (nauki techniczne i medycyna) posiada już platformę cyfrową, a w odniesieniu do nauk humanistycznych wskaźnik ten wynosi $84 \%$. Zakłada się, że w odniesieniu do tych ostatnich w następnym dziesięcioleciu tylko zaledwie $5 \%$ czasopism będzie wychodziło w wersji wyłącznie tradycyjnej, papierowej, pozostałe zaś będą albo hybrydowe, albo czysto elektroniczne ${ }^{10}$. Z pewnością w Polsce tak wysoki procent cyfryzacji czasopisma osiągną nie w 2020 r., lecz o jedną dekadę później. Wynika to z kilku czynników: ciągłego braku wyrównywania cywilizacyjnego poziomu życia w ramach UE, ale także opóźnionego doceniania wartości narzędzi elektronicznych w pracy naukowej historyka edukacji, braku elastyczności w warunkach wyboru między tradycyjnymi a nowoczesnymi technikami pracy umysłowej.

Można powiedzieć, że jest jeszcze niewystarczające zrozumienie nowej jakości, jaką jest cyfrowa informacja naukowa. Świadczy o tym duże rozproszenie informacji w Internecie, szczególnie wówczas, gdy chcemy dotrzeć do węższych kategorii wyszukiwania (np. czasopisma historyczno-pedagogiczne). Historia edukacji jako dyscyplina, pomimo istnienia Towarzystwa Historii Edukacji integrującego bodaj wszystkie środowiska historyków wychowania w Polsce, nie posiada własnej platformy elektronicznej oferującej recenzowane teksty naukowe w systemie Open Acces (OA), e-książki czy elektronicznych repozytoriów dokumentów. Szczególnie wartościową formą publikacji tekstów naukowych są czasopisma działające we wspomnianym systemie OA, czyli pełnotekstowe publikacje dostępne bezpłatnie w Sieci ${ }^{11}$.

Spośród dotąd wydawanych czasopism w całości poświęconych historiografii edukacyjnej należy wymienić „Przegląd Historyczno-Oświatowy”, „Rozprawy z Dziejów Oświaty” oraz „Biuletyn Historii Wychowania”. Najdłużej wychodzący PHO nie posiada wersji elektronicznej, zawartość tego czasopisma prezentuje Polska Bibliografia Literacka $^{12}$, podobnie „Rozprawy z Dziejów Oświaty” ${ }^{\prime 13}$, natomiast najmłodsze czasopismo - „Biuletyn Historii Wychowania” posiada w Internecie tylko winietę, bez dostępu do pełnych tekstów (z wypowiedzi redaktora naczelnego tego periodyku wynika, że wkrótce sytuacja ta ulegnie zmianie i będzie to ze wszech miar korzystne także i z tego względu, że BHW otrzymał 4 punkty). Są również czasopisma, w których jednym z działów jest historiografia pedagogiczna. Przykładem może być „Edukacja i Dialog”, która archiwizuje w swojej elektronicznej bazie numery pierwotnie wydane jako publikacje papierowe. Towarzystwo Historii Edukacji nie posiada na swojej platformie periodyku co

${ }^{10}$ M. i M. Nahotko, Stopień cyfryzacji polskich czasopism naukowych, http://nahotko.webpark.pl/xvinib. pdf.

11 Do tej grupy należy zaliczyć wychodzące od 2006 r. czasopismo obejmujące tematykę pogranicza pedagogiki, historiografii i filozofii - „Pedagogika Filozoficzna on-line” ISSN 1898-0910, będące składnikiem wortalu pedagogiki filozoficznej. http://www.pedagogika-filozoficzna.edu.pl/index.php?opiton=com_content\&task=view\&id=9\&Itemid $=13$.

$12 \mathrm{http} / / /$ pbl.ibl.poznan.pl/dostep/index.php?s=d_biezacy\&f=zapisy\&p_zrodlo $=178$.

$13 \mathrm{http} / / /$ pbl.ibl.poznan.pl/dostep/index.php?s=d_biezacy\&f=zapisy\&p_zrodlo=1626 
budzi zdziwienie, biorąc pod uwagę blisko dziesięcioletni okres jego istnienia. Generalnie można powiedzieć, że cyfryzacja nie wkroczyła jeszcze w pełni na grunt historiografii pedagogicznej, gdy tymczasem historia kultury czy historia filozofii korzysta z ogromnych możliwości komunikacji elektronicznej. Przykładem wysoko cenionych wirtualnych czasopism są: dla historii - „Kultura i Historia” ${ }^{14}$, a dla filozofii „Diametros” ${ }^{\text {. }}$.

Pewną propozycją dla nowoczesnego rozwoju dyscypliny i udziału polskich uczonych w ogólnoświatowych przemianach komunikacji naukowej jest stworzenie czasopism realizujących ideę Open Access - czyli otwartych czasopism on-line. Jak dotąd żadne z czasopism w całości zorientowanych na historiografię edukacyjną nie realizuje tego standardu, a wśród publikacji wyłącznie on-line - obok prezentowanego wcześniej pisma „Kultura i Historia” - jedynym tytułem w Polsce z dziedziny filozofii wychowania i jej historii jest „Pedagogika Filozoficzna on-line” wychodząca w powiązaniu z Zakładem Pedagogiki Filozoficznej UŁ. Idea nowoczesnych czasopism naukowych prezentowanych na platformie wyłącznie elektronicznej nie jest nowa, ma ona swoją reprezentację w międzynarodowych dążeniach do wypracowania globalnej i interaktywnej bazy wiedzy ludzkiej, której częścią są m.in. czasopisma elektroniczne i repozytoria. Sformalizowanym wyrazem owych dążeń jest Deklaracja Berlińska z 2003 r. kontynuująca Budapeszteńską Inicjatywę Wolnego Dostępu (2002 r.), zgodnie z którą otwarty dostęp jest definiowany jako „możliwość wykorzystania nieograniczonych źródeł wiedzy i dziedzictwa kulturowego, która powinna być aprobowana przez społeczność naukową"16.

Cyfrowa Biblioteka Narodowa jest dopiero na etapie przygotowywania publikacji czasopiśmienniczych do digitalizacji ${ }^{17}$. Nie występuje tam jeszcze czasopiśmiennictwo z interesującego nas obszaru. Podobnie w największej narodowej inicjatywie - Polskiej Bibliotece Internetowej, choć znajduje się wiele pozycji z zakresu historiografii pedagogicznej, to czasopism o interesującej nas tematyce jeszcze nie ma ${ }^{18}$.

Czasopisma digitalizowane można odnaleźć w Kujawsko-Pomorskiej Bibliotece Cyfrowej, natomiast więcej tytułów o nachyleniu pedagogicznym znajduje się w Wielkopolskiej Bibliotece Cyfrowej, są tam m.in. takie periodyki (o różnej wartości merytorycznej), jak: „Bluszcz”, „Dziennik Domowy”, „Filareta”, „Głos Kobiety”, „Kościół i Szkoła”, „Myśl i Czyn”, „Orędownik Naukowy”, „Oświata”, „Warta”. Zasoby te zawierają treści o charakterze historyczno-pedagogicznym. W Dolnośląskiej Bibliotece Cyfrowej znajdziemy także, ale nieliczne, czasopisma o tematyce wychowawczej, jak np.: „Ruch” ${ }^{\prime 19}$.

Istnieje również bardzo interesujący projekt Biblioteki Narodowej dotyczący digitalizacji czasopism. Jest on dopiero w fazie początkowej, na dzień 1 września $2006 \mathrm{r}$.

${ }^{14}$ http://www.kulturaihistoria.umcs.lublin.pl/

$15 \mathrm{http}: / / w w w . d i a m e t r o s . i p h i l s . i j . e d u . p l$

${ }^{16}$ Deklaracja Berlińska w sprawie otwartego dostępu do wiedzy w naukach ścisłych i humanistyce, tłum.

B. Bednarek-Michalska, J. Grześkowiak, http://ebib.oss.wroc.pl/2005/63/deklaracja.php

17 http://www.polona.pl/dlibra

18 http://www.pbi.edu.pl/opbi_celepbi.html

19 http://www.dbc.wroc.pl/dlibra/results?action=SearchAction\&QI=C0175B688938D3A588736988A3DED647-2 
bowiem na kolekcję składało się 13 tytułów czasopism i 121 roczników. Przeniesienie dokumentów nastąpić miało nie ze źródeł oryginalnych, ale ze wspomnianych na wstępie mikrofilmów, na których w ciągu półwiecza utrwalono ok. 3500 tytułów czasopism. Wśród digitalizowanych czasopism jest najstarszy polski periodyk „Merkuriusz Polski”. W Internecie można dotrzeć do Federacji Bibliotek Cyfrowych (obecnie jest to 40 bibliotek), a wśród nich jest także Pedagogiczna Biblioteka Cyfrowa obejmująca niestety tylko $0,16 \%$ digitalizowanych publikacji. Statystyki, które prezentują wielkość digitalizowanych tekstów pokazują jak niewielką ich część stanowią czasopisma i druki zwarte z kręgu pedagogiki i jej dziejów ${ }^{20}$. Trzy największe biblioteki cyfrowe (Wielkopolska, PBI, Kujawsko-Pomorska) zawierają ponad 50\% wszystkich digitalizowanych publika$\mathrm{cji}^{21}$. Ciekawym, acz nieprowadzącym do tekstów on-line rozwiązaniem jest Elektroniczna Biblioteka Pedagogiczna, w której zasobach znajdują się bazy bibliograficzne artykułów z czasopism ${ }^{22}$.

$\mathrm{Na}$ koniec trochę futurystyki. W najwyżej rozwiniętych państwach mówi się już o przejściu od „konwencjonalnych” czasopism elektronicznych do tzw. archiwów elektronicznych, które mają inną filozofię gromadzenia wytworów naukowych niż tradycyjne czasopisma - te papierowe i te elektroniczne. Teksty umieszczane są w repozytoriach i opisane za pomocą słów kluczowych tworzą luźny zbiór dokumentów, które mogą być przeszukiwane przez czytelników na wiele sposobów. Repozytorium jest stale rosnącym magazynem bez rytmu wydań i z inną koncepcją recenzowania opartą na kilku podstawowych wektorach (szybkość, spontaniczność, niezależność, powszechność). Repozytoria mają już własną, hierarchiczną strukturę, której podstawą są repozytoria osobowe uczonych, gdzie umieszcza się zazwyczaj preprinty, ale także i postprinty, ponad nimi znajdują się repozytoria dziedzinowe, wydziałowe, instytucjonalne i na szczycie tej piramidy usytuowane są repozytoria narodowe. Jeszcze bardziej nowatorskim pomysłem jest sugestia tworzenia - choć brzmi to w naszym języku pejoratywnie - ,wirtualnej nauki”, której istotą byłby tzw. kolaboratoria, czyli wspólna naukowa praca oparta na elektronicznej komunikacji i bezpośrednim dostępie do danych. Przywraca się także dawne pojęcie gildii naukowców, dziś interpretowane jako grupa/środowisko ludzi pracujących nad jednym zagadnieniem ponad wszelkimi podziałami (państwowymi, politycznymi, gospodarczymi itp.) i wymieniających między sobą informacje (publikacje) bez pośrednictwa jakichkolwiek instytucji. Realizacja tej idei wymaga całkowitej przemiany mentalności uczonych i przeorganizowania warsztatów.

Zanim pojawią się analizy porównawcze warto przyjrzeć się badaniom społeczności użytkowników czasopism elektronicznych w innych krajach, ponieważ typowe zjawi-

${ }^{20} \mathrm{~W}$ związku z tym widzę tu ogromną potrzebę i zarazem zobowiązanie dla środowiska polskich pedagogów, aby zadbało o to, by książki i periodyki z szeroko rozumianych nauk o wychowaniu znalazły się w możliwie najbogatszym wyborze w ogólnie dostępnej Sieci. Płyną z tego wielorakie korzyści - teksty rzadkie staną się własnością publiczną, druki zagrożone rozpadnięciem się będą przechowywane bez wielokrotnego ich dotykania, ich kopie elektroniczne bowiem będą wystarczającym substytutem, dostęp do literatury nie będzie ograniczony ani czasem pracy bibliotek, ani kolejnością wypożyczeń, być może będzie można zmniejszyć nakłady druku nowych pozycji do liczby wymaganej tzw. egzemplarzem obowiązkowym itp.

${ }^{21} \mathrm{http}: / /$ fbc.pionier.net.pl/owoc/lib-stats

${ }^{22}$ http://e-pedagogiczna.edu.pl/33,11.html 
ska najprawdopodobniej będą za jakiś czas wyznacznikiem naszej rzeczywistości. Otóż okazuje się, że po pierwsze - czasopisma elektroniczne są tam w powszechnym użyciu, a wśród użytkowników prym wiodą naukowcy i studenci wyższych lat, po wtóre - stopień wykorzystania czasopism elektronicznych jest uwarunkowany dostępem do nich (OA) oraz wygodą obsługi interfejsu, przy czym czasopisma renomowane są czytane nawet bez względu na wygodę. Istotny jest również wiek użytkowników i oczywista jest konkluzja, że do czasopism elektronicznych sięgają częściej młodsi niż starsi. Najciekawsze jednak wydaje się generalne przesłanie wynikające z cytowanych badań, mianowicie dostrzegalna jest tendencja malejąca, jeśli chodzi o czytelnictwo czasopism elektronicznych naśladujących tradycyjne, a zdecydowanie rośnie wyszukiwanie tematyczne, co wyraźnie wskazuje na potrzebę rozbudowywania repozytoriów ${ }^{23}$. Zwracają na to uwagę polscy bibliotekarze, bardzo zresztą krytycznie ustosunkowani do papierowych deklaracji władz, pozornie tylko dążących do wprowadzenia w życie strategii pod nazwą ePolska. Ich zdaniem jednym z najważniejszych celów w tym zakresie powinno być „,budowanie zasobów wiedzy: baz danych, czasopism elektronicznych, bibliotek cyfrowych, repozytoriów" ${ }^{24}$, co oczywiście wymaga nie tylko zaangażowania się w realizację tej strategii różnych środowisk w Polsce, ale również pociąga za sobą finansowanie projektu na tak wielką skalę, że możliwe to jest w ramach państwa wspieranego dotacjami unijnymi.

Jako użytkownicy powstających baz jesteśmy żywo zainteresowani rozwojem zarówno czasopism elektronicznych, jak i repozytoriów, zaś środowisku polskich bibliotekarzy należą się słowa uznania za czynione wysiłki i osiągnięte rezultaty, pomimo nikłego nadal wsparcia władz RP.

\section{Pedagogical historiography in traditional print periodicals and electronic publications}

\section{Summary}

Scientific and research periodicals play an extremely important part in popularizing (and promoting) results of research studies, though this role is not equally appreciated across different domains of science. This becomes apparent if we compare the number of traditional and electronic titles of periodicals in such disciplines as medicine, natural science and exact science on the one side, and those that represent the humanities, broadly understood, on the other. The advantage of electronic content in the former group is overwhelming.

Nowadays, we use two terms in relation to periodicals available online and launched on the electronic platform. The terms make a distinction between a degree of their involvement in the cyber space. "Digitalization" means a certain transitory state between traditional periodicals in print and virtual publications; in other words, a product of "digitization" is an electronic copy (e.g. a scanned text) of a text originally published in print, whereas the notion of "digital authorship (the

\footnotetext{
23 Por. M. Nahotko, Naukowe czasopisma, s. 130-131.

${ }^{24}$ B. Bednarek-Michalska, Wolny dostęp do informacji i wiedzy czy wykluczenie edukacyjne? Trendy światowe a Polska, http://ebib.oss.wroc.pl/2005/63/michalska.php
} 
author as digital producer), in Polish: cyfryzacja" deals with an entirely electronic publication with specific properties underlined by multimedia and hypertext capabilities.

Digital research information as an entirely new quality has not been yet appropriately appreciated. The history of education as a discipline of research does not have its own electronic platform that would offer peer-reviewed research papers in Open Access (OA), e-books or electronic document repositories. For the time being, the most recent Polish periodical within this discipline, i.e. Biuletyn Historii Wychowania, has only a front page, ToCs and a masthead available online, without access to full-text electronic content. 